Article

\title{
Effects of Ornamental Plant Density and Mineral/Plastic Media on the Removal of Domestic Wastewater Pollutants by Home Wetlands Technology
}

\author{
Luis Carlos Sandoval-Herazo ${ }^{1,2}{ }^{\circledR}$, Alejandro Alvarado-Lassman ${ }^{1}(\mathbb{D}$, \\ María Cristina López-Méndez ${ }^{2} \mathbb{D}$, Albino Martínez-Sibaja ${ }^{1}$, Alberto A. Aguilar-Lasserre ${ }^{1}$ D, \\ Sergio Zamora-Castro ${ }^{3}$ and José Luis Marín-Muñiz ${ }^{4, *}$ \\ 1 División de Estudios de Posgrados e Investigación, Tecnológico Nacional de México/Instituto Tecnológico de \\ Orizaba, Oriente 9, Emiliano Zapata Sur, C.P. Orizaba 94320, Veracruz, Mexico; \\ lcsandovalh@gmail.com (L.C.S.-H.); lassman@prodigy.net.mx (A.A.-L.); albino3_mx@yahoo.com (A.M.-S.); \\ albertoaal@hotmail.com (A.A.A.-L.) \\ 2 División de Estudios Posgrado e Investigación, Tecnológico Nacional de México/Instituto Tecnológico \\ Superior de Misantla, Misantla, Veracruz, C.P. Misantla 93821, Veracruz, Mexico; \\ mclopezm@misantla.tecnm.mx \\ 3 Faculty of Engineering, Construction and Habitat, Universidad Veracruzana Bv. Adolfo Ruíz Cortines 455, \\ Costa Verde, C.P. Boca del Rio 94294, Veracruz, Mexico; szamora@uv.mx \\ 4 Sustainable Regional Development Academy, El Colegio de Veracruz, Xalapa 91000, Veracruz, Mexico \\ * Correspondence: soydrew@hotmail.com
}

Academic Editor: Giorgio Vilardi

Received: 11 September 2020; Accepted: 6 November 2020; Published: 12 November 2020

\begin{abstract}
Wastewater treatment (WWT) is a priority around the world; conventional treatments are not widely used in rural areas owing to the high operating and maintenance costs. In Mexico, for instance, only $40 \%$ of wastewater is treated. One sustainable option for WWT is through the use of constructed wetlands (CWs) technology, which may remove pollutants using cells filled with porous material and vegetation that works as a natural filter. Knowing the optimal material and density of plants used per square meter in CWs would allow improving their WWT effect. In this study, the effect of material media (plastic/mineral) and plant density on the removal of organic/inorganic pollutants was evaluated. Low (three plants), medium (six plants) and high (nine plants) densities were compared in a surface area of $0.3 \mathrm{~m}^{2}$ of ornamental plants (Alpinia purpurata, Canna hybrids and Hedychium coronarium) used in polycultures at the mesocosm level of household wetlands, planted on the two different substrates. Regarding the removal of contaminants, no significant differences were found between substrates $(p \geq 0.05)$, indicating the use of plastic residues (reusable) is an economical option compared to typical mineral materials. However, differences $(p=0.001)$ in removal of pollutants were found between different plant densities. For both substrates, the high density planted CWs were able to remove COD in a range of $86-90 \%, \mathrm{PO}_{4}-\mathrm{P} 22-33 \%, \mathrm{NH}_{4}-\mathrm{N}$ in $84-90 \%$, $\mathrm{NO}_{3}-\mathrm{N} 25-28 \%$ and $\mathrm{NO}_{2}-\mathrm{N} 38-42 \%$. At medium density, removals of $79-81 \%, 26-32,80-82 \%, 24-26 \%$, and $39-41 \%$, were observed, whereas in CWs with low density, the detected removals were $65-68 \%$, $20-26 \%, 79-80 \%, 24-26 \%$ and $31-40 \%$, respectively. These results revealed that higher COD and ammonia were removed at high plant density than at medium or low densities. Other pollutants were removed similarly in all plant densities $(22-42 \%)$, indicating the necessity of hybrid CWs to increase the elimination of $\mathrm{PO}_{4}-\mathrm{P}, \mathrm{NO}_{3}-\mathrm{N}$ and $\mathrm{NO}_{2}-\mathrm{N}$. Moreover, high density favored 10 to $20 \%$ more the removal of pollutants than other plant densities. In addition, in cells with high density of plants and smaller planting distance, the development of new plant shoots was limited. Thus, it is suggested that the appropriate distance for this type of polyculture plants should be from 40 to $50 \mathrm{~cm}$ in expansion to real-scale systems in order to take advantage of the harvesting of species in these and allow species of greater foliage, favoring its growth and new shoots with the appropriate distance to compensate, in the short time, the removal of nutrients.
\end{abstract}


Keywords: wetlands; wastewater; water pollutants; density of plants; phytoremediation

\section{Introduction}

Water pollution and low investment in wastewater treatment (WWT) in developing countries results in a high risks for human health and ecosystems [1,2]. This condition creates the obligation to find both economic and ecological alternatives for WWT based on the needs of these regions, located mostly in tropical and inter tropical areas with little attention to such water problem $[3,4]$. Constructed wetlands (CWs) are a sustainable option to treat wastewater. These engineering systems can mimic the functions of natural wetlands through physical, chemical and biological processes [5], where the role of plants and support media or substrates is essential.

The substrates serve as the support of the living organisms, provide storage for many contaminants and permanent physical support for plants [6,7]. Conventionally, the use of minerals such as tezontle, sand, zeolite and gravel are very common in CWs as a substrate or filling material $[8,9]$. However, these are usually the most expensive materials during the construction of CWs owing to their commercial use in the construction industry and this is a limitation in rural communities with limited economic resources [10].

In this sense, materials with the same or better functionality and lower commercial costs such as the polyethylene terephthalate (PET) are necessary. Despite the fact that PET causes major negative environmental effects, the roughness and porosity of certain parts of a PET bottle such as the cap, neck and bottom can be functional as a substrate in CWs [11]. Another important component in CWs is the vegetation, commonly called macrophytes in natural wetlands, that have been used in CW systems (Phragmites australis, a species of the genus Typha spp., Scirpus spp. and C. papyrus), which provide oxygen to the systems in the substrates, favoring the growth of aerobic bacterial communities. They also contribute to the removal of pollutants by absorption (15 to $25 \%$ ) of residual water elements used for their development [12,13]. In this last decade, new ornamental flowering plants (OFP, eg., Anthurium spp., Canna spp., Heliconiaceae spp., Spathiphyllum wallisii, and Zantedeschia aethiopica), not typical of natural wetlands that favor aesthetic aspects of the CWs without affecting the removal function (up to $80 \%$ of organic and inorganic compounds), have been evaluated to facilitate the adoption of this technology in small communities $[14,15]$. The majority of studies regarding CWs have been focused on effect of natural wetland macrophytes, different mineral substrates or water flow type on pollutant removal $[12,16,17]$. However, little is known about the effects of OFP and the density (number of plants) on the biogeochemical role in WWT. Similarly, little has been studied about the reuse of plastic substrate as filter media. The objective of this study was to compare the removal effect on organic and inorganic pollutants of domestic wastewater of the plant density (three OFP species, one of each one, three OFPs, with two of each species and six OFPs, using two of each species), the use of mineral substrate (porous rock river -PRR) and the reutilization of PET residues as filter media. In this regard, two hypotheses were put forth: (1) High plant density would provide more oxygen to the substrate increasing the aerobic conditions and therefore the pollutant removal efficiency. (2) Knowing the roughness and structure of certain components of PET bottles, such residues can have a similar action as filter media compared with mineral substrates.

\section{Results and Discussion}

\subsection{Control Parameters}

Table 1 shows results of the control parameters monitored during the study period. The water temperature after passing through the systems was reduced by $2{ }^{\circ} \mathrm{C}$ on average. In spite of this, it was found to be in a suitable range (between 16.5 and $32^{\circ} \mathrm{C}$ ) to favor the processes of removal of contaminants in the CWs. On the side of increased bacterial activity, which is initiated at a temperature 
of $>20^{\circ} \mathrm{C}$ [18] the results of this study are in these ranges (Table 1). As for the appropriate $\mathrm{pH}$ in CWs to promote most of the biological reactions, this occurs in ranges from 6 to 8 [19]. In this study, an average of $6.8(\mathrm{pH})$ was detected for the influent, whereas in the effluent the values increased statistically $(p<0.05$, Table 1$)$. In systems with vegetation, the average $\mathrm{pH}$ was 7.7 , while in systems without vegetation it was 7.8. These ranges are suitable for promoting biological reactions in CWs. In addition to the above, the low presence of DO in the systems (Table 1), could have favored the increase in $\mathrm{pH}$ [20]. In relation to the electrical conductivity (EC), $1601.3 \pm 291.2$ was observed in the influent and was significantly reduced $(p>0.05)$ in both systems with vegetation $(30-36 \%)$ and without vegetation (34\%) (Table 1). In the literature, it is reported that for a hydraulic retention time less than 3 days, this behavior is not frequent [21]. These results could be due to the capture of micro and macro elements of ions by plants and eliminated through radical absorption and sedimentation of suspended particles [22].

The dissolved oxygen (DO), shown in Table 1, increases considerably in systems with vegetation $(p>0.05)$, while in systems without vegetation the increase was not significant $(p>0.05)$ in relation to the influent. The presence of DO indicates the type of conditions found in the systems: aerobic, anaerobic/anoxic for biological processes [23]. Therefore, the presence of oxygen in systems with greater vegetation than in non-planted systems could be due to its release in the radical zone [24,25]. In relation to the total dissolved solids (TDS), these mainly include organic salts and residues, therefore, in terms of their decrease in treatment systems it becomes an indicator of their effectiveness [26]. In this study, a significant decrease of TDS was found $(p>0.05)$ in relation to the value of the influent (Table 1), these values found, after treatment in CWs, are within the limits allowed by the United States Environmental Protection Agency [27] which indicates that $500 \mathrm{mg} \mathrm{L}^{-1}$ is a suitable range for discharges to surface bodies and are consistent with those reported by other studies in similar conditions using CWs, where reduced values have been found after treatment in these systems [28].

An environmental characteristic, such as the intensity of light, played an important role in the development of vegetation. In this study, the range of light oscillated between 2000-5000 lux, 3000-10,000 lux, and 3000-35,000 lux at 17:00, 14:00 and 9:00 h, they favored the development of plants without inhibiting their growth or physiological health. In the same way, such light values favored the observed temperatures for good biological functioning in the system (Figure 1).

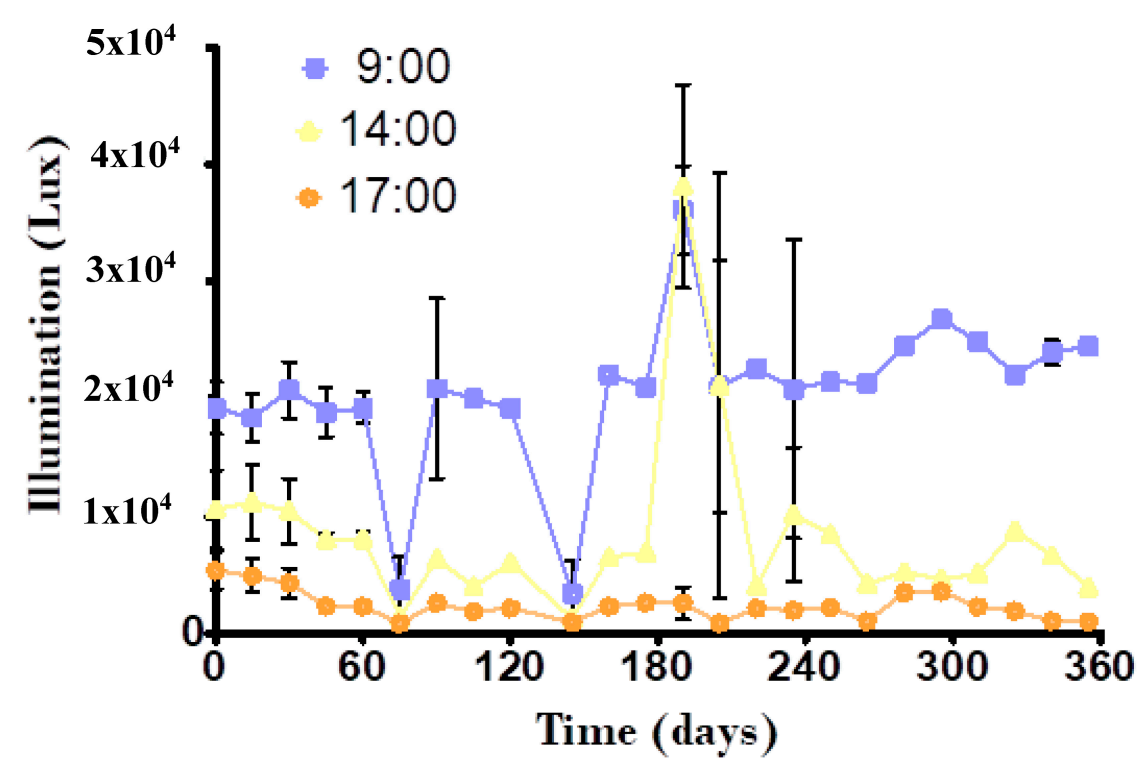

Figure 1. Intensity of light in three different times of day $(9,14$ and $17 \mathrm{~h})$ during the study. 
Table 1. Water quality parameters in influent and enfluent in wetlands.

\begin{tabular}{|c|c|c|c|c|c|c|c|c|}
\hline \multicolumn{9}{|c|}{ Wetlands Plants in Different Substrates } \\
\hline Parameters & $\begin{array}{c}\text { Low Density } \\
\text { PET }\end{array}$ & $\begin{array}{c}\text { Medium } \\
\text { Density PET }\end{array}$ & $\begin{array}{c}\text { High Density } \\
\text { PET }\end{array}$ & $\begin{array}{c}\text { Low Density } \\
\text { PRS }\end{array}$ & $\begin{array}{c}\text { Medium } \\
\text { Density PRS }\end{array}$ & $\begin{array}{c}\text { High Density } \\
\text { PSR }\end{array}$ & Control PET & Control PRS \\
\hline \multicolumn{9}{|l|}{ Water temperature $\left({ }^{\circ} \mathrm{C}\right)$} \\
\hline Influent & \multicolumn{8}{|c|}{$26.45 \pm 0.29$} \\
\hline Effluent & $24.62 \pm 0.22$ & $25.13 \pm 0.20$ & $24.83 \pm 0.21$ & $24.92 \pm 0.21$ & $25.105 \pm 0.22$ & $25.01 \pm 0.23$ & $24.88 \pm 0.27$ & $24.70 \pm 0.24$ \\
\hline \multicolumn{9}{|l|}{$\mathrm{pH}$} \\
\hline Influent & \multicolumn{8}{|c|}{$6.80 \pm 0.47$} \\
\hline Effluent & $7.72 \pm 0.43$ & $7.70 \pm 0.37$ & $7.65 \pm 0.41$ & $7.69 \pm 0.35$ & $7.60 \pm 0.42$ & $7.63 \pm 0.36$ & $7.89 \pm 0.32$ & $7.76 \pm 0.38$ \\
\hline \multirow{4}{*}{$\begin{array}{r}(\mu \mathrm{S} / \mathrm{cm}) \\
\text { Influent } \\
\text { Effluent } \\
\mathrm{DO}(\mathrm{mg} / \mathrm{L})\end{array}$} & & & & & & & & \\
\hline & \multicolumn{8}{|c|}{$1601.33 \pm 291.15$} \\
\hline & $1116.63 \pm 41.39$ & $1128.71 \pm 38.66$ & $1028.23 \pm 47.33$ & $1079.62 \pm 45.18$ & $1014.46 \pm 40.32$ & $1190.70 \pm 178.96$ & $1041.62 \pm 58.85$ & $1064.25 \pm 56.67$ \\
\hline & & & & & & & & \\
\hline Influent & \multicolumn{8}{|c|}{$1.7 \pm 0.42$} \\
\hline Effluent & $3.6 \pm 0.51$ & $3.9 \pm 0.26$ & $6.7 \pm 0.13$ & $3.4 \pm 0.60$ & $4.1 \pm 0.34$ & $5.8 \pm 0.72$ & $2.4 \pm 0.54$ & $2.1 \pm 0.21$ \\
\hline \multicolumn{9}{|l|}{ TDS (mg/L) } \\
\hline Influent & \multicolumn{8}{|c|}{$670.96 \pm 14.79$} \\
\hline Effluent & $529.08 \pm 15.13$ & $507.77 \pm 16.39$ & $505.11 \pm 19.59$ & $480.61 \pm 18.66$ & $496.01 \pm 20.23$ & $458.71 \pm 18.13$ & $585.01 \pm 13.89$ & $595.63 \pm 11.75$ \\
\hline
\end{tabular}

Values are given as the average \pm standard error $(n=48)$; different letters indicate significant differences between the columns at the $95 \%$ significance level. PSR, Porous stone river; PET, polyethylene terephthalate. 


\subsection{Plant Growth and Flower Production}

\subsubsection{Alpina purpurata}

Alpina purpurata is an ornamental plant listed as an exotic tropical plant in the global weed compendium [29]. It has been cultivated in tropical areas, being capable of surviving in totally or partially flooded soils [30]. Owing to this, it was used as an emerging plant in subsurface horizontal flow CWs. The plant development data of $A$. purpurata are shown in Figure 2. No significant differences $(p>0.05)$ were found in the development of the species in the two-culture media (PET and PRS). The tropical conditions where the study was developed favored its adaptation in CWs indicating that the environmental conditions were adequate for the development of this species [31]. During the study, it was found that plants planted in densities of one individual in polycultures of three plants (low density), by cell, plants produced on average 10 shoots of A. pulpurata in both substrates during the 12 months of study, while in a system with polycultures of medium density (three plants), for A. pulpurata, for each CW, only six shoots were generated on average, independently of the material support (PET/PRS). In polycultures of nine individuals (high density) A. purpurata, produced four shoots per plant. This could be due to the presence of a greater number of plants in the same area $\left(0.36 \mathrm{~m}^{2}\right)$, given that in the systems it was possible to generate more competition for the nutrients present in wastewater and hindering the growth of tillers. It should be noted that these species are not commonly used in CWs. In this sense, these data are the first reports of their development in this type of system, finding that the distance of planted and the volume of seedlings significantly influenced their development. As for the adequate distance to improve their development in this study, it was $50 \mathrm{~cm}$ and in low density conditions. In relation to the production of flowers, no flowers were produced during the study, which could be due to the fact that, during the flowering period, this plant under terrestrial conditions grows from 1.5 to $2 \mathrm{~m}$ tall in an approximate period of 8 months [32]. However, in this study very small plants $(10$ to $25 \mathrm{~cm})$ were planted and they did not show the same growth behavior as in their natural state, given the new conditions to which they were exposed for development. Thus, studies using a longer evaluation period are necessary to know the rate of flowering of these species in CWs and encourage their ornamental use in future designs.

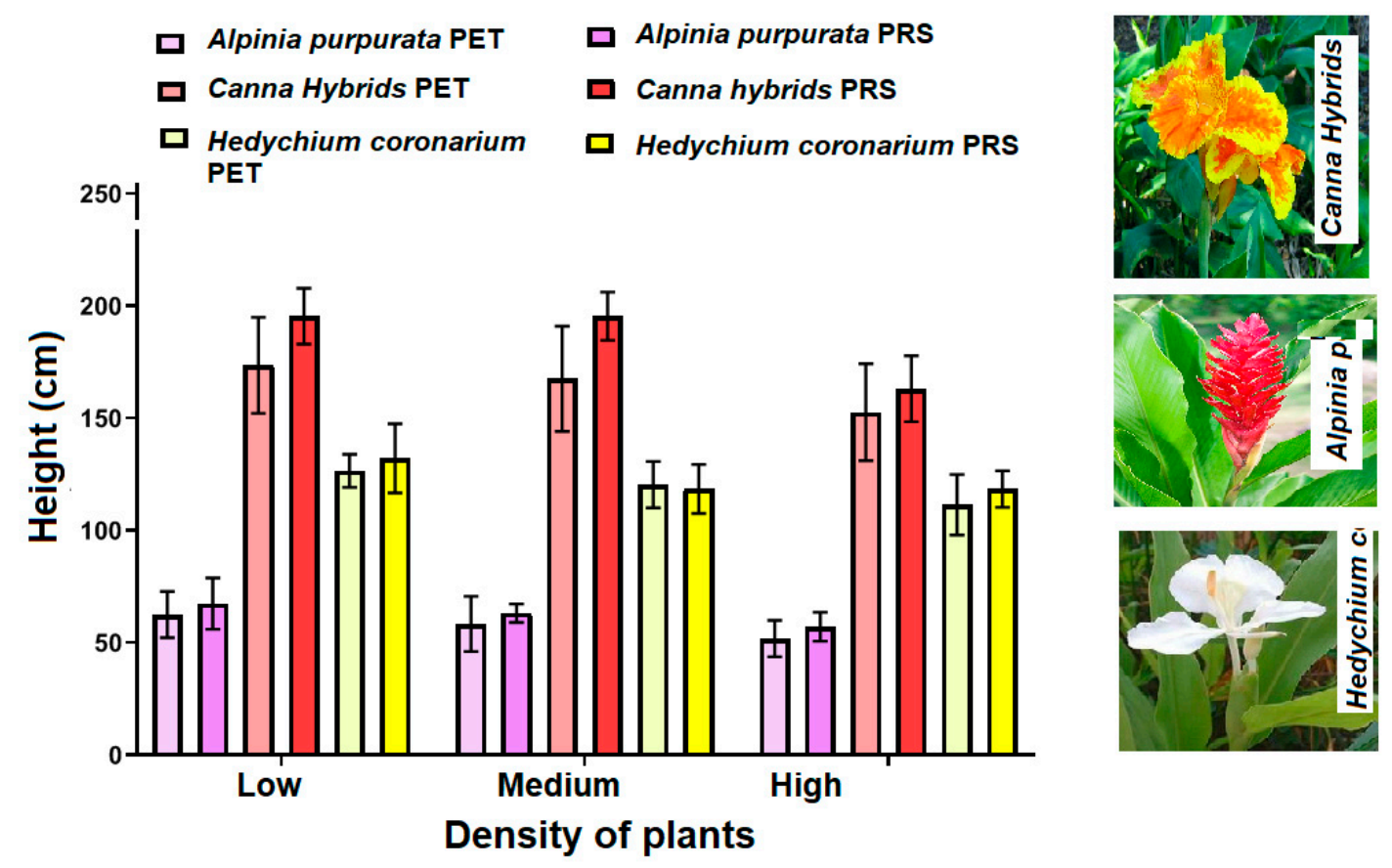

Figure 2. Average maximum height of the vegetation under study in the three different plant densities (under PET and PRS substrates). 


\subsubsection{Hedychium coronarium}

Tropical floriculture is in early stages in Mexico, although the cultivation of Hedychium coronarium shows great potential in various humid tropical areas of the country. This is an herbaceous plant that develops at temperatures above $10^{\circ} \mathrm{C}$ [33]. The ambient temperature conditions that occurred in the study area $\left(20-26^{\circ} \mathrm{C}\right)$, as well as the light intensity (Figure 1), showed ranges that could favor the proper development of $H$. coronarium; these can reach up to $3 \mathrm{~m}$ high in their natural state. In this study, the PET and PRS substrates were used as media using different planting distances for this plant (Table 1). These differ greatly from those recommended for cultivation (1 to $1.5 \mathrm{~m}$ distance between them), which could indicate why the plants did not achieve heights they should have presented ( 2 to $2.5 \mathrm{~m}$ high) in 12 months of study.

Figure 2 shows that regardless of the substrate, on average the plants grew up to $1.5 \mathrm{~m}$ high without significant differences between substrates $(p=0.621)$, but failed to produce flowers, although their typical flowering period is from 7 to 8 months after planting [34]. This could be due to the conditions of constant saturation to which they were exposed, such as vegetation saturation, water quality or the reduced space where they were planted. Consequently, new studies are required where this plant is used as emergent vegetation in large-scale systems that allow its better development, more distances for planting and with longer study periods in order to evaluate its flower production in CWs.

\subsubsection{Canna hybrids}

Canna hybrids is a tropical plant that is easy to grow and does not die easily because it is resistant to adverse conditions, and even when irrigated with highly polluted water, they reproduce quickly and generally flower 1 year after having been planted. It is considered an invasive plant when it grows wild among controlled crops [35]. In this study, light ranges (Figure 1) were found to be lower than those reported as optimal for cultivation of this OFP, which are between 40,000 and 60,000 lux [36], however, this did not hinder their development.

Significant differences $(p=0.001)$ were found between the vegetation planted in PET and PRS substrates (Figure 2). The plants presented an average of $30 \mathrm{~cm}$ more in height in PRS substrate than in PET, although the growth is among the averages reported on the growth of plants (1 to $3 \mathrm{~m})$ [37]. All plants grew healthy and managed to produce on average 95 flowers per plant in PET and 98 in PRS; without finding significant differences in flower production between substrates $(p=1.00)$. Although the use of PET as a substrate in CWs is not common, the plants managed to adapt and grow healthily as in any other common medium such as PRS. According to the growth conditions that are shown in their natural state, these plants generate about 60 flowers per plant in 12 months [38]. However, in this study the flowering increased up to $40 \%$, compared to when it is cultivated in soil, which could be due to the availability of constant nutrients present in wastewater.

\subsection{Contaminants Concentration in Influents and Effluents from CWs}

The chemical oxygen demand (COD) is the amount of oxygen needed to oxidize organic carbon completely to $\mathrm{CO}_{2}, \mathrm{H}_{2} \mathrm{O}$ and ammonium. COD does not differentiate between biologically oxidizable organic matter and biologically inert materials [26]. The COD influent concentrations on average were $353.96 \pm 9.21 \mathrm{mg} / \mathrm{L}$. After treatment with CWs, in both substrates it was found that in systems with vegetation and PET the COD was $78.57 \pm 2.64 \mathrm{mg} / \mathrm{L}$, and $76.23 \pm 6.98 \mathrm{mg} / \mathrm{L}$ with PRS (Figure 3b). CWs without vegetation had averages of concentrations of $142.55 \pm 1.93 \mathrm{mg} / \mathrm{L}$ and $138.54 \pm 5.29 \mathrm{mg} / \mathrm{L}$ in PET and PRS substrates, respectively (Figure 3a,b). The COD data, after treatment, fulfilled the regulations of the European Union for protection of water quality for discharge into lakes (COD; $<125 \mathrm{mg} / \mathrm{L})$. These results may be due to the greater presence of oxygen (Table 1 ) in systems with vegetation where the greatest COD reductions in CWs were presented after treatment [39]. The COD parameters indicate the ability to reduce oxygen present in receiving bodies of water and 
are the main parameters for measuring the content of organic matter in wastewater $[40,41]$. On the other hand, the COD indicates the presence of non-municipal origin substances in the water [42].

PET
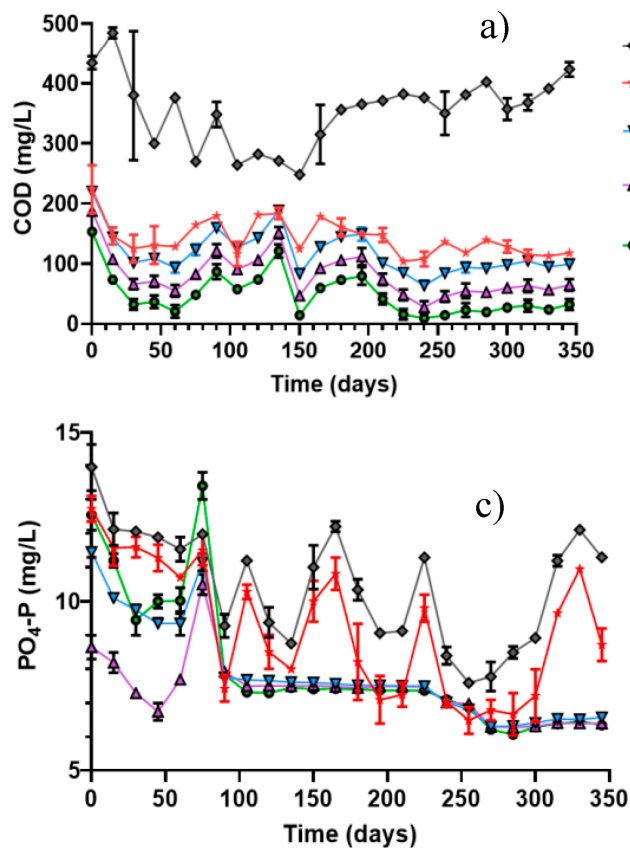

PRS

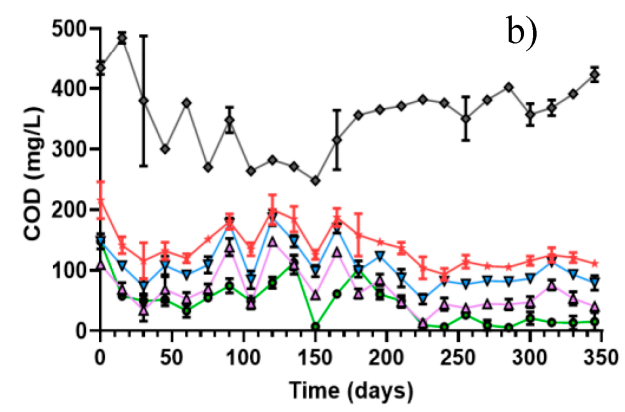

d)

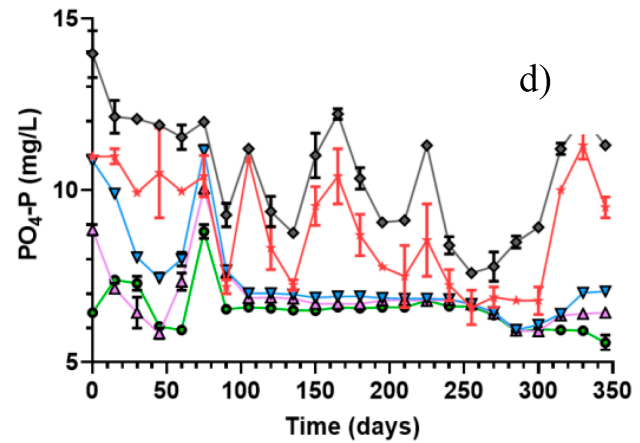

Figure 3. Contaminant concentration, (a) COD in PET, (b) COD in PRS, (c) $\mathrm{PO}_{4}-\mathrm{P}$ in $\mathrm{PET}$ and (d) $\mathrm{PO}_{4}-\mathrm{P}$ in PRS in effluents and influents in CWs with PET and PRS substrates.

In this sense, it is essential that they be removed before discharging wastewater into rivers. In this study, systems without vegetation showed removal efficiencies between 58 and 59\% in both substrates (Figure $4 a, b$ ). In general, the average of removal found in CWs with vegetation was $81 \%$ and consistent with the reported by $[5,14]$ with $78 \%$, which is the average of removals found in systems with polyculture of ornamental plants in CWs fed with domestic wastewater. However, significant differences were found according to plant densities $(p=0.001)$ in both substrates and no significant differences were observed regarding the substrate $(p=0.07)$, but different plant density showed significantly higher average of COD removal $(p=0.001)$. CWs with low plant density $(65-68 \%)<$ medium density $(79-81 \%)<$ high plant density (86-90\%) (Figure 4a,b). This behavior could be due to the release of radical oxygen given the higher plant density in the systems. This information is consistent with that reported by [43], which indicated that the higher the plant density, the better the COD removal in horizontal flow CWs. These results show a clearer picture of the role of vegetation in CWs. However, new studies with a greater presence of organic matter in wastewater are suggested to deal with CWs in high plant polyculture density. 
\% Removal in PET

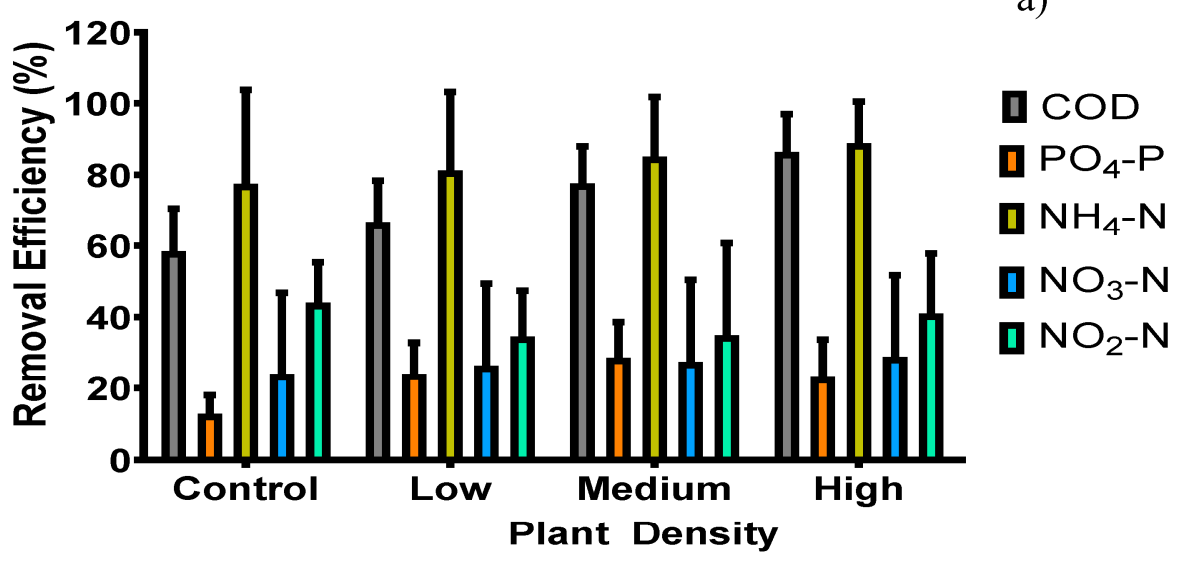

\% Removal in PRS

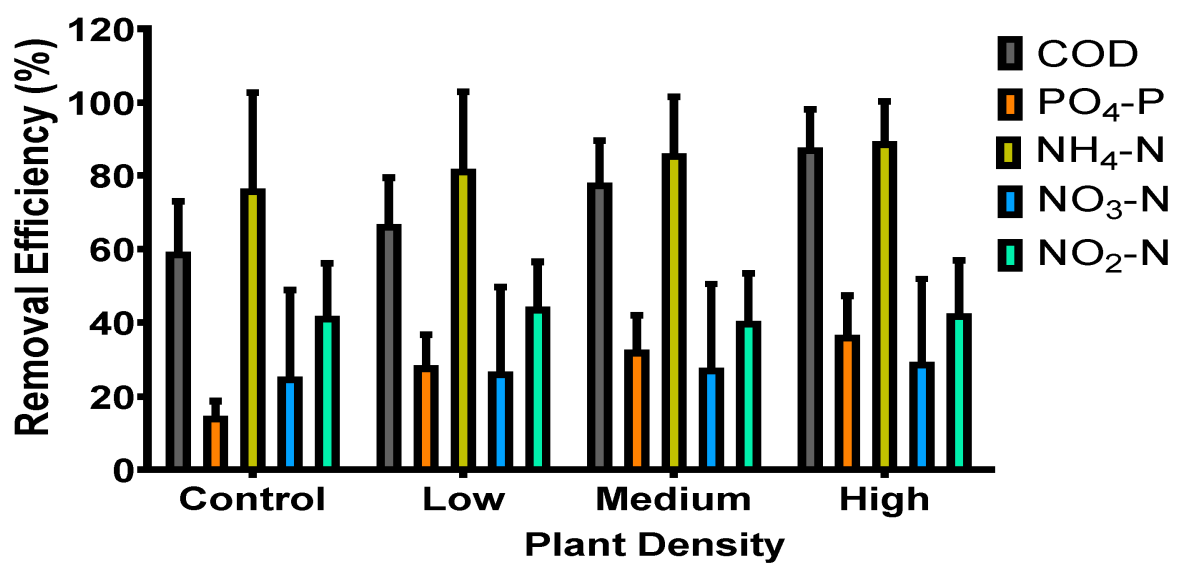

Figure 4. CWs contaminants: (a) Removal in PET and (b) Removal in PRS.

The phosphate concentration $\left(\mathrm{PO}_{4}-\mathrm{P}\right)$ in the influent was $10.46 \pm 0.25 \mathrm{mg} / \mathrm{L}$. This value decreased significantly $(p=0.001)$ in CWs with vegetation $7.74 \pm 0.11 \mathrm{mg} / \mathrm{L}$ and $6.69 \pm 0.15 \mathrm{mg} / \mathrm{L}$ in PET and PRS respectively (Figure 3c,d), compared to the systems without plants $(9.18 \pm 012 \mathrm{mg} / \mathrm{L}$ in PET and $8.92 \pm 0.25 \mathrm{mg} / \mathrm{L}$ in PRS), which could be due to the absorption of $\mathrm{PO}_{4}-\mathrm{P}$ ion by plants for growing development [44], as shown in Figure 2. This behavior is explainable given the main phosphorus removal mechanisms in wetlands (by substrate adsorption and assimilation by plants [45]. However, these values do not comply with the Mexican standard which specifies phosphorus as total phosphorus (PT) and establishes a maximum allowable limit of $5 \mathrm{mg} / \mathrm{L}$. In biologically treated domestic wastewater, $\mathrm{PO}_{4}-\mathrm{P}$ is approximately $80 \%$ of PT. Therefore, it is recommended to evaluate these substrates in conjunction with others that have a greater ionic capacity to attract the phosphorus present in domestic wastewater with phosphate content greater than or equal to the values present in this study.

In the PET substrate, the removal in systems without the presence of vegetation was on average $10 \%, 20 \%$ in CWs with low density, $26 \%$ with medium density where the highest removal of $\mathrm{PO}_{4}-\mathrm{P}$ occurred; $p=0.001$ ) and $22 \%$ of removal in CWs with high density [46], indicating that phosphorus in its different forms can be used by plants for their development with better results in tropical climates, where the plants are harvested continuously so that their development is not interrupted until the plants reach maturity. That might explain the results obtained in this study, where the plants managed to develop considerably (Figure 2) and the phosphate could have been used for its development and flowering [18]. The ionic interaction with the substrates was not as relevant in this study, perhaps because of the substrates used (PET and PRS), since using them in CWs is unconventional and precise 
mechanisms of their functioning are unknown. The elimination in these could be due to the adoption in the microbial films that were developed in the PET substrate. Regarding the removals in PRS substrate, significant differences were found $(p=0.001$ ), among all treatments in controls without vegetation $20 \%$ $<$ in treatments with three species of plants $26 \%<$ in treatment with six individuals of plants $32 \%<$ in treatment of nine individuals of $33 \%$ plants (Figure $4 a, b$ ).

In comparison to the treatments in PET and PRS, the phosphate removal behavior in PET substrate was as expected, given that it apparently did not have an effect on the removal of this compound, while in the PRS treatments a positive effect was shown, but not greater than those reported in the consulted literature [47].

Ammonium is removed in CWs, through the action of aerobic and anaerobic microorganisms, taking into account that under anaerobic conditions the reductions are slow [48], which may explain its behavior in this study. The concentrations of ammonium (Figure 5a,b) in the influent oscillated in a ranged of $18.88 \pm 0.51 \mathrm{mg} / \mathrm{L}$; these were significantly reduced $(P=0.001)$ in presence of plants and in the systems without plant species. For both substrates from the first 50 days, the removal in the CWs began to be observed, the elimination of pollutants were almost at $100 \%$ on the 125 days of study. On average $2.81 \pm 0.24 \mathrm{mg} / \mathrm{L}$ of $\mathrm{NH}_{4}-\mathrm{N}$ were observed in systems with plants for both substrates, while in units without vegetation $3.23 \pm 0.14 \mathrm{mg} / \mathrm{L}$ were detected, these results were lower than the limit established by the Mexican law about ion discharge in rivers (NMX-AA-026-SCIF-2001, 25 to $50 \mathrm{mg} / \mathrm{L})$.
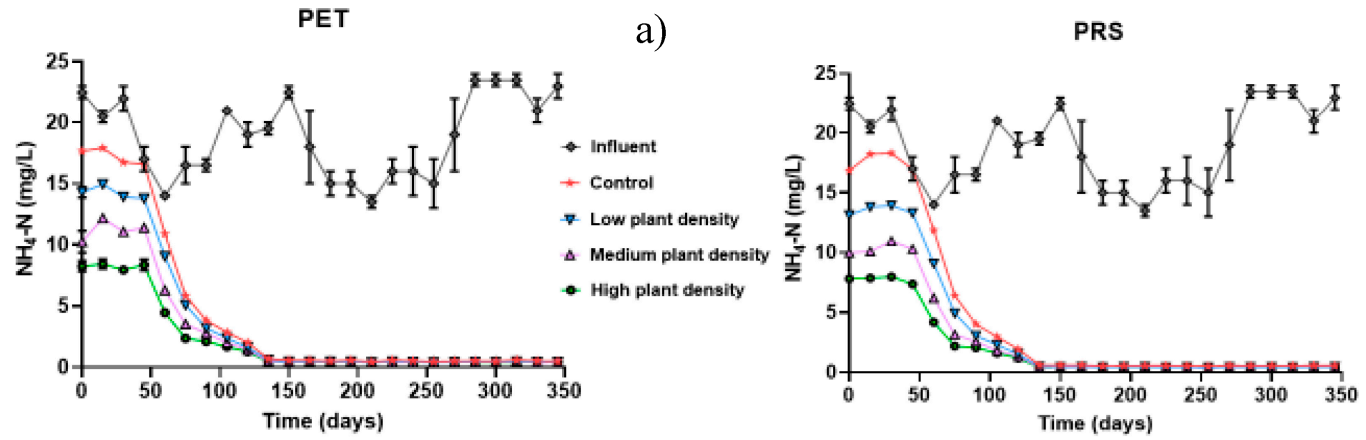

b)

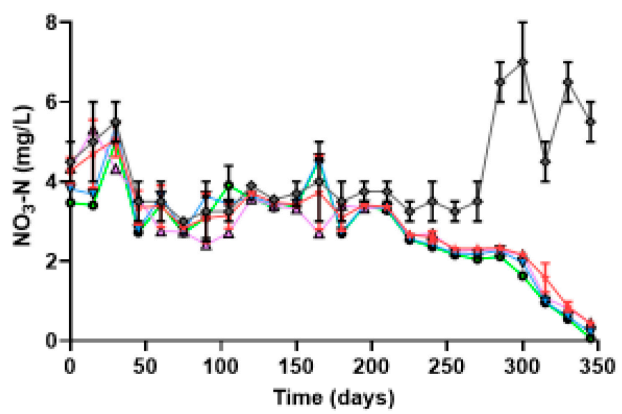

c)

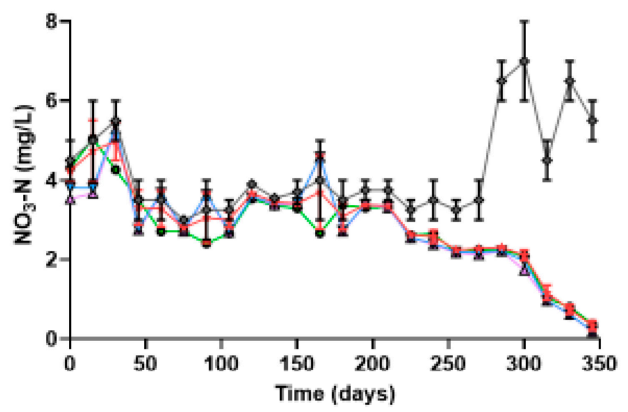

d)
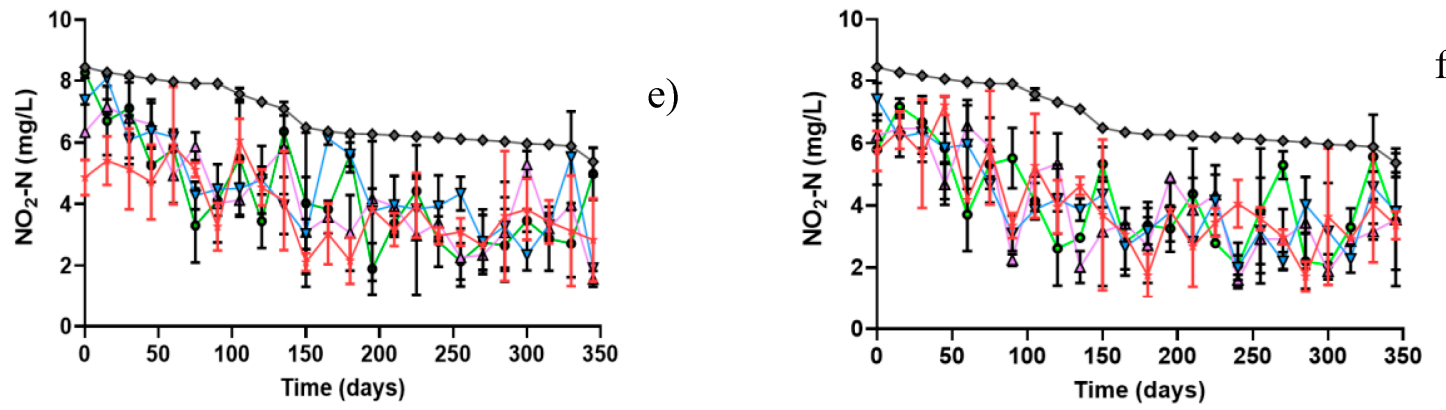

Figure 5. Concentrations of the contaminants, (a) $\mathrm{NH}_{4}-\mathrm{N}$ in PET, (b) $\mathrm{NH}_{4}-\mathrm{N}$ in PRS, (c) $\mathrm{NO}_{3}-\mathrm{N}$ in PET, (d) $\mathrm{NO}_{3}-\mathrm{N}$ in PRS, (e) $\mathrm{NO}_{2}-\mathrm{N}$ in PET, and (f) $\mathrm{NO}_{2}-\mathrm{N}$ in PRS substrates. 
The ability of horizontal flow CWs to oxidize ammonia nitrogen is low (nitrification), given the low availability of aerobic zones within the wetland (only in the rhizosphere zone) (Table 1) [49]. Despite this, the eliminations in this study (Figure $4 a, b)$ were highly significant $(p=0.0012)$ : in a system with three plants the removal on average was 79 and $80 \%$; in systems with six plants 80 and $82 \%$; in systems with nine plants 61 and 64\%, and in controls without vegetation 84 and $90 \%$ in PET and PRS substrate respectively. There were no significant differences $(p=0.086)$ between substrates, in contrast with $(p=0.094)$ plant density, as well as between controls. These results are higher than those reported by [50], who used plastic rings as substrates; a combination of zeolite and fly ash with more calcium element; and fly ash using microphytes as emergent vegetation, finding eliminations between 40 and $58 \%$ of $\mathrm{N}-\mathrm{NH}_{4}$.

For nitrate removal, it is important to describe that nitrogen removal from water and wastewater involve a combination of aerobic nitrification and anaerobic denitrification, a significant part of organic nitrogen is converted to ammonia, which is oxidized in aerobic condition by Nitrosomonas and Nitrobacter. Nitrification implies a chemolithoautotrophic oxidation of ammonia to nitrate under strict aerobic conditions. In HSSF-CWs the aerobic conditions occur mainly in the rhizosphere zone. [51,52]. The concentration of $\mathrm{NO}_{3}-\mathrm{N}$ (Figure $5 \mathrm{c}, \mathrm{d}$ ) in the influent was $4.22 \pm 0.18 \mathrm{mg} / \mathrm{L}$ for both substrates, and after treatment it decreased significantly $(P=0.001)$ in systems with vegetation, $2.97 \pm 0.10 \mathrm{mg} / \mathrm{L}$ in PET and $2.91 \pm 0.18$ in PRS respectively were detected, but not in systems without vegetation ( $3.65 \pm 0.83 \mathrm{mg} / \mathrm{L}$ and $2.81 \pm 0.18 \mathrm{mg} / \mathrm{L}$ in PET and PRS substrate).

Another way of reducing $\mathrm{NO}_{3}-\mathrm{N}$ is through denitrification. $\mathrm{NO}_{3}$ - is reduced in anoxic conditions by heterotrophic bacteria (such as Pseudomonas, Micrococcus, Achromobactor and Bacillus), in this process, denitrifying bacteria decreases inorganic nitrogen such as nitrate and nitrite into innocuous fundamental nitrogen gas [48,52]. In HSSF-CWs, anoxic conditions occur where there is no contact with the vegetation roots.

CWs filled with PET and with presence of vegetation ranged from $24-30 \%$ (Figure $4 a$ ) and showed significantly higher average nitrate removal efficiency than systems without plants $(21 \%)$. No significant differences were observed for such ion respect to plant densities $(p \geq 0.05)$, while in CWs with PRS substrate (Figure $4 \mathrm{~b}$ ) the nitrate removal was similar in all the units, regardless of the plant density (25-30\%). The results found in this study differ from those expected in horizontal flow CWs for the elimination of $\mathrm{N}^{-\mathrm{NO}_{3}}$, since anaerobic conditions, a carbon source and denitrifying bacteria favor the elimination of this compound [53]. The previously described since the concentrations of ammonium (Figure $5 \mathrm{a}, \mathrm{b}$ ) were relatively higher, nitrates were produced that could affect the elimination mechanisms of this CWs.

The concentration of $\mathrm{NO}_{2}-\mathrm{N}$ in the influent was $6.84 \pm 0.14 \mathrm{mg} / \mathrm{L}$ (Figure $5 \mathrm{e}, \mathrm{f}$ ), while in the influents with vegetation was $4.38 \pm 0.13 \mathrm{mg} / \mathrm{L}$ in PET and $3.99 \pm 0.24 \mathrm{mg} / \mathrm{L}$ in PRS, in CWs without vegetation it was $3.87 \pm 0.10 \mathrm{mg} / \mathrm{L}$ and $4.04 \pm 0.25 \mathrm{mg} / \mathrm{L}$ in PET and PRS respectively (Figure $5 \mathrm{e}, \mathrm{f}$ ). The $\mathrm{NO}_{2}-\mathrm{N}$ elimination was favored in CWs (Figure 4a,b), finding significant differences $(p=0.001$ ) between substrates and plant density in cells with controls without vegetation 41 and $30 \%$; in cells with three plants 31 and $40 \%$; in cells with six plants 39 and $41 \%$, and in cells with nine plants 38 and $42 \%$ in PET and PRS substrates, respectively. These results may be due to the high removal of ammonium that could contribute to the production of nitrites as shown in Figure 4.

\section{Materials and Methods}

\subsection{Study Area}

This study was carried out in Pastorias, Actopan (June 2016-May 2017). This community is in the central mountainous area of the State of Veracruz, Mexico ( $-96^{\circ} 57^{\prime} 08^{\prime \prime}$ and $19^{\circ} 55^{\prime} 83^{\prime \prime}$ S). The climate in the area is classified as semi-warm humid with rains throughout the year $(45 \%)$, warm-humid with rains throughout the year (38\%) and warm-humid with abundant rains in summer (17\%), with higher temperatures in June and lower in January, at an altitude of $1900 \mathrm{~m}$ above sea level. The average 
annual rainfall is $947.1 \mathrm{~mm}$ and the average annual temperature is between $20-26^{\circ} \mathrm{C}$, which are typical conditions of the subtropical areas of America [54].

\subsection{Constructed Wetlands (CWs) Systems' Characteristics}

The CW systems were Horizontal Subsurface Flow (HSSF) cells. Fourteen mesocosms constructed with cement and blocks were used as experimental units $(0.70 \mathrm{~m}$. high, $1.5 \mathrm{~m}$. long and $0.24 \mathrm{~m}$. wide; Figure 6). They were installed in a rural dwelling of three people and employed as a WWT home. The water before entering the mesocosms had a pretreatment in a filter settler, in a $1500 \mathrm{~L}$ tank. All the 14 experimental units (Figure 6) were filled from bottom to a height of $10 \mathrm{~cm}$ with PRR of 8 to $15 \mathrm{~cm}$ in diameter. Then, seven mesocosms were filled with $60 \mathrm{~cm}$ of PRR as a substrate (2.5 to $3.5 \mathrm{~cm}$ diameter, and an uneven surface with 0.4 average porosity), taken from the local Topiltepec river. The other seven cells were filled with $50 \mathrm{~cm}$ of PET residues (rough sections were taken and with folds of recycled bottles used for beverages like water and soft drinks, with 2.5 to $3.5 \mathrm{~cm}$ in diameter, in order to provide a favorable surface for the development of bacterial communities, with a $0.5 \%$ porosity). For cells with PET, $10 \mathrm{~cm}$ of PPR were added under the PET to prevent plastic buoyancy; this last fraction $(10 \mathrm{~cm})$ did not interfere with the treatment system.

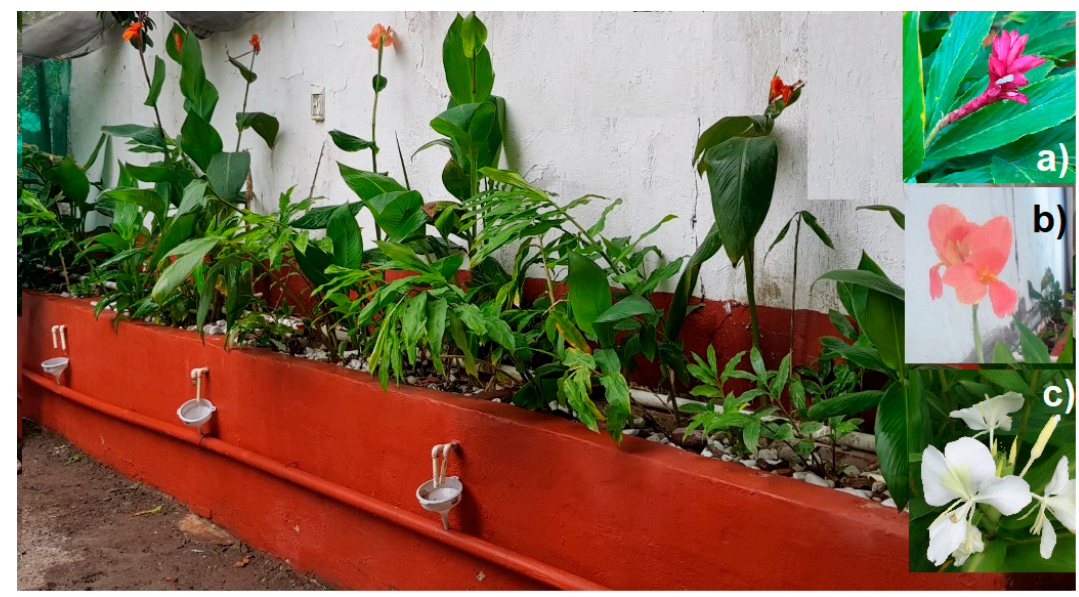

d)

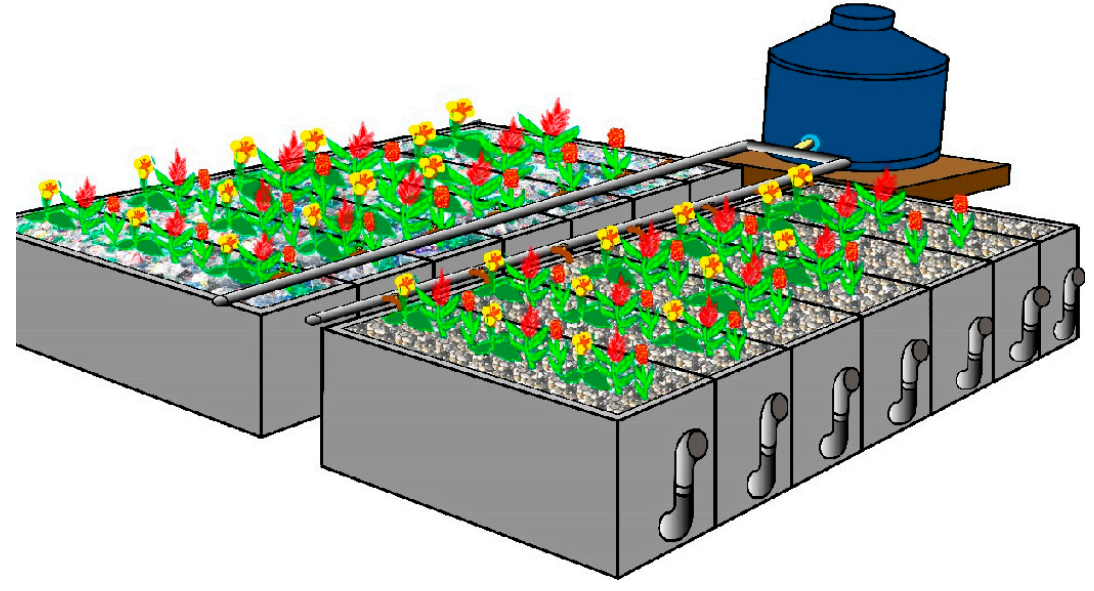

Figure 6. Constructed wetland systems. (a) Alpinia purpurata, (b) Canna hybrids, (c) Hedychium coronarium, (d) Scheme of CWs in study.

Two filled experimental units, one from PRR and one from PET functioned as controls without vegetation. In the other twelve cells, six were filled with PRR and six filled with PET. The configuration of vegetation density for each different porous media was (15 to $20 \mathrm{~cm}$ high each plant): three plants with one sample of Alpinia purpurata + one sample of Canna hybrids + one 
sample of Hedychium coronarium (low density, $0.4 \mathrm{~m}$ distance between plants). Two mesocosms were planted with OFPs consisting of two A. purpurata + two C. hybrids + two H. coronarium plants (medium density, $0.2 \mathrm{~m}$ of distance between plants). The other two mesocosms of each filter media were planted with OFPs that included three A. purpurata + three C. hybrids + three H. coronarium plants (high density, $0.1 \mathrm{~m}$ of distance between plants). The ornamental plants were collected from areas near the study sites to favor their adaptation to new flood conditions to which they were exposed. All mesocosms were operated with a hydraulic retention time of 4 days.

\subsection{Sampling and Analysis}

From the day the tank was fed with $100 \%$ residual water and during the study period, a sample of the influent and effluent of each mesocosm was taken every 15 days. The pollutants analyzed were $\mathrm{COD}, \mathrm{PO}_{4}-\mathrm{P}, \mathrm{NH}_{4}-\mathrm{N}, \mathrm{NO}_{3}-\mathrm{N}$ and $\mathrm{NO}_{2}-\mathrm{N}$ in duplicates by standard methods [55]. Total dissolved solids (TDS), electrical conductivity (EC), $\mathrm{pH}$, dissolved oxygen (DO) and water temperature were measured with a H198194 multiparameter meter (Hanna, Ciudad de México, Mexico) placed in the influent and effluent streams of the mesocosms. In addition to these data, the ambient temperature and light intensity were measured every 15 days with a HTC-1 hydrometer (Uplayteck, Ciudad de México, Mexico) and a HIELEC-MS8233-2000 (STEREN, Veracruz, Mexico) lux meter, respectively, at times of 9:00, 14:00 and 17:00 h; estimating and recording the average of each measurement. The height of the plants was measured with a tape measure and the number of flowers was recorded every 30 days.

\subsection{Statistic Analysis}

The response variables were $\mathrm{COD}, \mathrm{PO}_{4}-\mathrm{P}, \mathrm{NH}_{4}-\mathrm{N}, \mathrm{NO}_{3}-\mathrm{N}$, and $\mathrm{NO}_{2}-\mathrm{N}$, as well as the height of the plant and the number of flowers. Statistical differences between treatments were estimated using a two-way ANOVA with plant density and substrates as factors, followed by evidence of least significant differences (LSD), with a significance level of $5 \%$. All statistical analyses were performed with version 16.1.0 of Minitab (ver. 16, State college, PA, USA).

\section{Conclusions}

The use of Alpinia purpurata, Canna hybrids and Hedychium coronarium in polycultures for treatment of domestic wastewater in mesocosms of CWs favored the elimination of organic matter and nitrogen compounds, while phosphate ion was less removed by such species during the 350 days of study. Owing to this, their use in CW designs is recommended. In addition, Canna hybrids flowers showed greater flowering compared to their normal development in the natural state. However, the species Alpinia purpurata and Hedychium coronarium failed to produce flowers. More studies over a longer period are suggested in order to understand the flowering behavior of these plants in CWs. Apparently, in these systems this may require periods longer than 12 months. Regarding plastic materials, PET was proven to be a suitable support medium for use in large-scale CWs, since it allows the proper development of vegetation and does not limit the removal of pollutants compared to PRS which is a more common and more expensive substrate than PET because the latter is reusable in CWs.

Regarding the growth of the vegetation, it was observed that there was a better and greater growth in plants with a lower planting density, as well as a greater production of tillers. Studies on CWs with a greater effective area are necessary to obtain a clearer picture of the landscape and behavior of tropical ornamental plants in relation to their planting density in these biosystems. Plant density shows a positive effect on the elimination of pollutants, especially on COD and ammonia, however, in cells where there were more plants with a smaller planting distance, the development of new plant shoots was limited. In this sense, it is recommended that the appropriate distance for this type of polyculture plants be 40 to $50 \mathrm{~cm}$ in expansion in real-scale systems, in order to take advantage of the harvesting of species in these and allow species of greater foliage such as Alpinia purpurata and Hedychium coronarium which develop properly and can produce flowers in CWs. 
Author Contributions: Conceptualization, J.L.M.-M.; Data curation, M.C.L.-M.; Formal analysis, A.M.-S.; Funding acquisition, A.A.-L.; Investigation, L.C.S.-H., and J.L.M.-M.; Methodology, L.C.S.-H., A.A.-L., A.A.A.-L., and S.Z.-C.; Resources, A.A.-L., and S.Z.-C.; Software, M.C.L.-M.; and A.A.A.-L.; Visualization, A.A.A.-L.; Writing-original draft, L.C.S.-H., and J.L.M.-M.; Writing-review \& editing, A.M.-S. and S.Z.-C. All authors have read and agreed to the published version of the manuscript.

Funding: This study was partially funded by the Tecnológico Nacional de México with the Convocatoria de Apoyo a la Investigación Científica y Tecnológica 2017 program (469.17-PD).

Acknowledgments: The first author of the present study would like to thank the Instituto Tecnológico de Orizaba for allowing his doctoral studies to be undertaken in the Engineering Science program of PNPC-CONACYT.

Conflicts of Interest: The authors declare no conflict of interest.

\section{References}

1. Villalobos, A.; Díaz, J.A. Calidad del Ambiente, Vulnerabilidad y Acciones Ante el Cambio Climático: Costa Rica en Perspectiva Comparada. Av. Hacia Política Econ. Sosten. Contexto Cambio Climático Costa Rica 2018, 3, 64. Available online: https://www.academia.edu/36802095/Calidad_del_ambiente_vulnerabilidad_ y_acciones_ante_el_cambio_clim\%C3\%A1tico_Costa_Rica_en_perspectiva_comparada (accessed on 8 October 2020).

2. Zhindón, R.; Cartuche, D.; España, P.; Maldonado, M. Evaluación Ambiental de Aguas Residuales: Estero y Manglar el Macho de la Ciudad de Machala. Conf. Proc. 2018, 2, 2. Available online: http://investigacion. utmachala.edu.ec/proceedings/index.php/utmach/article/view/277/226 (accessed on 10 July 2020).

3. Zhang, D.; Jinadasa, K.; Gersberg, R.M.; Liu, Y.; Tan, S.K.; Ng, W.J. Application of constructed wetlands for wastewater treatment in tropical and subtropical regions (2000-2013). J. Environ. Sci. 2015, 30, 30-46. [CrossRef] [PubMed]

4. Guven, H.; Dereli, R.K.; Ozgun, H.; Ersahin, M.E.; Ozturk, I. Towards sustainable and energy efficient municipal wastewater treatment by up-concentration of organics. Prog. Energy Combust. Sci. 2019, 70, 145-168. [CrossRef]

5. Leiva, A.M.; Núñez, R.; Gómez, G.; López, D.; Vidal, G. Performance of ornamental plants in monoculture and polyculture horizontal subsurface flow constructed wetlands for treating wastewater. Ecol. Eng. 2018, 120, 116-125. [CrossRef]

6. Wang, M.; Zhang, D.Q.; Dong, J.W.; Tan, S.K. Constructed wetlands for wastewater treatment in cold climate-A review. J. Environ. Sci. 2017, 57, 293-311. [CrossRef] [PubMed]

7. Zhang, L.; Lyu, T.; Zhang, Y.; Button, M.; Arias, C.A.; Weber, K.P.; Brix, H.; Carvalho, P.N. Impacts of design configuration and plants on the functionality of the microbial community of mesocosm-scale constructed wetlands treating ibuprofen. Water Res. 2018, 131, 228-238. [CrossRef]

8. Wu, H.; Zhang, J.; Ngo, H.H.; Guo, W.; Shuang, L.; Liang, S.; Fan, J.; Liu, H. A review on the sustainability of constructed wetlands for wastewater treatment: Design and operation. Bioresour. Technol. 2015, 175, 594-601. [CrossRef]

9. Lu, S.; Zhang, X.; Wang, J.; Pei, L. Impacts of different media on constructed wetlands for rural household sewage treatment. J. Clean. Prod. 2016, 127, 325-330. [CrossRef]

10. Marín-Muñiz, J.L. Humedales construidos en México para el tratamiento de aguas residuales, producción de plantas ornamentales y reuso del agua. Agroproductividad 2017, 10, 5. Available online: http://revistaagroproductividad.org/index.php/agroproductividad/article/view/1028/879 (accessed on 15 June 2020).

11. Sandoval-Herazo, L.C.; Alvarado-Lassman, A.; Marín-Muñiz, J.L.; Méndez-Contreras, J.M.; Zamora-Castro, S.A. Effects of the Use of Ornamental Plants and Different Substrates in the Removal of Wastewater Pollutants through Microcosms of Constructed Wetlands. Sustainability 2018, 10, 1594. [CrossRef]

12. Marín-Muñiz, J.L.; García-González, M.C.; Ruelas-Monjardín, L.C.; Moreno-Casasola, P. Influence of Different Porous Media and Ornamental Vegetation on Wastewater Pollutant Removal in Vertical Subsurface Flow Wetland Microcosms. Environ. Eng. Sci. 2018, 35, 88-94. [CrossRef]

13. Hernández-Vásquez, L.A.; Vallejo-Cantú, N.A.; Alvarado-Lassman, A.; Reyes-Rosas, S. Evaluación de la biodegradabilidad de un inóculo anaerobio pretratado térmicamente. Renew. Energy Biomass Sustain. 2019, 1, 65-71. Available online: https://aldeser.org/uploads/1/3/0/8/130818527/articulo_5_rb_s_vol1_no1.pdf (accessed on 12 May 2020). 
14. Zurita, F.; De Anda, J.; Belmont, M. Treatment of domestic wastewater and production of commercial flowers in vertical and horizontal subsurface-flow constructed wetlands. Ecol. Eng. 2009, 35, 861-869. [CrossRef]

15. Hernández, M.E.A. Humedales ornamentales con participación comunitaria para el saneamiento de aguas municipales en México. Rinderesu 2016, 1, 1-12. Available online: http://www.rinderesu.com/index.php/ rinderesu/article/view/16/32 (accessed on 20 May 2020).

16. Wu, S.; Austin, D.; Liu, L.; Dong, R. Performance of integrated household constructed wetland for domestic wastewater treatment in rural areas. Ecol. Eng. 2011, 37, 948-954. [CrossRef]

17. Hernández, M.E.; Galindo-Zetina, M.; Carlos, H.-H.J. Greenhouse gas emissions and pollutant removal in treatment wetlands with ornamental plants under subtropical conditions. Ecol. Eng. 2018, 114, 88-95. [CrossRef]

18. Morvannou, A.; Forquet, N.; Vanclooster, M.; Molle, P. Characterizing hydraulic properties of filter material of a vertical flow constructed wetland. Ecol. Eng. 2013, 60, 325-335. [CrossRef]

19. Wastewater engineering: Treatment, disposal and reuse. Adv. Water Resour. 1980, 3, 146. Available online: https://doi.org/10.1016/0309-1708(80)90067-6 (accessed on 8 October 2020). [CrossRef]

20. Pech, O.M.S.; Ocaña, G.L. Tratamiento de aguas residuales mediante humedales artificiales. Kuxulkab 2014, 19, 36. Available online: http://revistas.ujat.mx/index.php/kuxulkab/article/view/337 (accessed on 1 June 2020).

21. Díaz, F.J.; O'geen, A.T.; Dahlgren, R.A. Agricultural pollutant removal by constructed wetlands: Implications for water management and design. Agric. Water Manag. 2012, 104, 171-183. [CrossRef]

22. Zurita, F.; White, J.R. Comparative Study of Three Two-Stage Hybrid Ecological Wastewater Treatment Systems for Producing High Nutrient, Reclaimed Water for Irrigation Reuse in Developing Countries. Water 2014, 6, 213-228. [CrossRef]

23. He, K.; Lv, T.; Wu, S.; Guo, L.; Ajmal, Z.; Luo, H.; Dong, R. Treatment of Alkaline Stripped Effluent in Aerated Constructed Wetlands: Feasibility Evaluation and Performance Enhancement. Water 2016, 8, 386. [CrossRef]

24. Sun, H.; Xu, S.; Wu, S.; Wang, R.; Zhuang, G.; Bai, Z.; Deng, Y.; Zhuang, X. Enhancement of facultative anaerobic denitrifying communities by oxygen release from roots of the macrophyte in constructed wetlands. J. Environ. Manag. 2019, 246, 157-163. [CrossRef] [PubMed]

25. Białowiec, A.; Sobieraj, K.; Pilarski, G.; Manczarski, P. The Oxygen Transfer Capacity of Submerged Plant Elodea densa in Wastewater Constructed Wetlands. Water 2019, 11, 575. [CrossRef]

26. Lazcano, C.; Tsang, A.; Doane, T.A.; Pettygrove, G.S.; Horwáth, W.R.; Burger, M. Soil nitrous oxide emissions in forage systems fertilized with liquid dairy manure and inorganic fertilizers. Agric. Ecosyst. Environ. 2016, 225, 160-172. [CrossRef]

27. USEPA. A Handbook of Constructed Wetlands. A Guide to Creating Wetlands for Agricultural Wastewater, Domestic Wastewater, Coal Mine Drainage, Stormwater in the MidAtlantic Region. General Considerations; United States Environmental Protection Agency: Washintong, DC, USA, 2000; Volume 1, p. 32. Available online: http://biblioteca.cehum.org/bitstream/CEHUM2018/1287/1/Davis.\%20A\%20Handbook\% 20of\%20Constructed \%20Wetlands\%2C\%20Volume\%201\%2C\%20General\%20Considerations.pdf (accessed on 2 June 2020).

28. Méndez-Mendoza, A.S.; Bello-Mendoza, R.; Herrera-López, D.; Mejía-González, G.; Calixto-Romo, A. Performance of constructed wetlands with ornamental plants in the treatment of domestic wastewater under the tropical climate of South Mexico. Water Pr. Technol. 2015, 10, 110-123. [CrossRef]

29. Randall, R.P. Un Compendio Global de Malas Hierbas; Departamento de Agricultura y Alimentación de Australia Occidental: Perth, Australia, 2012; p. 1124. Available online: https://www.cabdirect.org/cabdirect/abstract/ 20173071957 (accessed on 2 June 2020).

30. Govaerts, R. Lista de Verificación Mundial de Zingiberaceae. Richmond, Londres: Royal Botanic Gardens, Kew 2013. Available online: https://www.cabdirect.org/cabdirect/abstract/20053205919 (accessed on 15 July 2020).

31. Kress, W.J.; Liu, A.-Z.; Newman, M.; Li, Q. The molecular phylogeny of Alpinia (Zingiberaceae): A complex and polyphyletic genus of gingers. Am. J. Bot. 2005, 92, 167-178. [CrossRef]

32. Ovando-Medina, I.; Adriano-Anaya, L.; Chávez-Aguilar, A.; Oliva-Llaven, A.; Ayora-Talavera, T.; Dendooven, L.; Gutiérrez-Miceli, F.; Salvador-Figueroa, M. Ex vitro Survival and Early Growth of Alpinia purpurata Plantlets Inoculated with Azotobacter and Azospirillum. Pak. J. Biol. Sci. 2007, 10, 3454-3457. [CrossRef] 
33. Baltazar-Bernal, O.; Zavala-Ruiz, J. Cultivo de Maracas (Zingiber spp.) en la Floricultura Tropical. AGROProductividad 2012, 5, 20-28. Available online: https:/go.gale.com/ps/anonymous?id=GALE\% 7CA382318766\&sid=googleScholar\&v=2.1\&it=r\&linkaccess $=$ fulltext\&issn $=\& p=I F M E \& s w=w($ accessed on 15 July 2020).

34. Loges, V.; Teixeira, M.D.C.F.; De Castro, A.C.R.; Costa, A.S. Colheita, pós-colheita e embalagem de flores tropicais em Pernambuco. Hortic. Bras. 2005, 23, 699-702. [CrossRef]

35. Prince, L.M. Phylogenetic relationships and species delimitation in Canna (Cannaceae). Divers. Phylogeny Evol. Monocotyledons 2010, 307-331. Available online: https://www.academia.edu/download/33163564/ Prince_2010.pdf (accessed on 15 July 2020).

36. Guzmán, A.B.M.; Palenius, H.G.N. Multiplicar Plantas Ornamentales De Agave Victoriae-Reginae (T. Moore). Jóvenes Cienc. 2017, 2, 1429-1433. Available online: http://148.214.90.90/index.php/jovenesenlaciencia/article/ view/1283 (accessed on 17 July 2020).

37. Konnerup, D.; Brix, H. Nitrogen nutrition of Canna indica: Effects of ammonium versus nitrate on growth, biomass allocation, photosynthesis, nitrate reductase activity and $\mathrm{N}$ uptake rates. Aquat. Bot. 2010, 92, 142-148. [CrossRef]

38. Gupta, A.; Maurya, R.; Roy, R.; Sawant, S.V.; Yadav, H.K. AFLP based genetic relationship and population structure analysis of Canna-An ornamental plant. Sci. Hortic. 2013, 154, 1-7. [CrossRef]

39. Chen, X.; Zhu, H.; Xu, Y.; Shutes, R.; Yan, B.; Zhou, Q. Effect of Aeration Modes and COD/N Ratios on Organic Matter and Nitrogen Removal in Horizontal Subsurface Flow Constructed Wetland Mesocosms. Water 2018, 10, 1530. [CrossRef]

40. Abdalla, K.Z.; Hammam, G. Correlation between biochemical oxygen demand and chemical oxygen demand for various wastewater treatment plants in Egypt to obtain the biodegradability indices. Int. J. Sci. Basic Appl. Res. 2014, 13, 42-48. Available online: https://pdfs.semanticscholar.org/2629/ 9e0f5b734f1b1b14de684c79caa4d91f081b.pdf (accessed on 20 July 2020).

41. Valente, J.P.S.; Padilha, P.M.; Silva, A.M.M. Oxigênio dissolvido (OD), demanda bioquímica de oxigênio (DBO) e demanda química de oxigênio (DQO) como parâmetros de poluição no ribeirão Lavapés/Botucatu - SP. Eclética Química J. 1997, 22, 49-66. [CrossRef]

42. Glenn, E.P.; Flessa, K.W.; Pitt, J. Restoration potential of the aquatic ecosystems of the Colorado River Delta, Mexico: Introduction to special issue on "Wetlands of the Colorado River Delta ". Ecol. Eng. 2013, 59, 1-6. [CrossRef]

43. Gagnon, V.; Chazarenc, F.; Comeau, Y.; Brisson, J. Influence of macrophyte species on microbial density and activity in constructed wetlands. Water Sci. Technol. 2007, 56, 249-254. [CrossRef]

44. Casierra-Martínez, H.A.; Charris-Olmos, J.C.; Caselles-Osorio, A.; Parody-Muñoz, A. Organic Matter and Nutrients Removal in Tropical Constructed Wetlands Using Cyperus ligularis (Cyperaceae) and Echinocloa colona (Poaceae). Water Air Soil Pollut. 2017, 228, 338. [CrossRef]

45. Lan, W.; Zhang, J.; Hu, Z.; Ji, M.; Zhang, X.; Li, F.; Yao, G. Phosphorus removal enhancement of magnesium modified constructed wetland microcosm and its mechanism study. Chem. Eng. J. 2018, 335, 209-214. [CrossRef]

46. Vymazal, J. Removal of nutrients in various types of constructed wetlands. Sci. Total. Environ. 2007, 380, 48-65. [CrossRef] [PubMed]

47. Rugaika, A.M.; Van Deun, R.; Njau, K.N.; Van Der Bruggen, B. Phosphorus recovery as calcium phosphate by a pellet reactor pre-treating domestic wastewater before entering a constructed wetland. Int. J. Environ. Sci. Technol. 2019, 16, 3851-3860. [CrossRef]

48. Torres Bojorges, Á.X.; Hernández Razo, N.A.; Fausto Urquieta, A.A.; Zurita, F. Evaluación de tres sistemas de humedales híbridos a escala piloto para la remoción de nitrógeno. Rev. Int. Contam. Ambient. 2017, 33, 37-47. [CrossRef]

49. Han, W.; Luo, G.; Luo, B.; Yu, C.; Wang, H.; Chang, J.; Ge, Y. Effects of plant diversity on greenhouse gas emissions in microcosms simulating vertical constructed wetlands with high ammonium loading. J. Environ. Sci. 2019, 77, 229-237. [CrossRef]

50. Shiwei, C.; Zhaoqian, J.; Peng, Y.; Yue, W.; Yin, W.; Wang, Y.; Wang, Y. Performance of constructed wetlands with different substrates for the treated effluent from municipal sewage plants. J. Water Reuse Desalination 2019, 9, 452-462. [CrossRef] 
51. Correa-Torres, S.N.; Gamarra, Y.; Salazar, A.A.; Pitta, N.M. Evaluación de la Remoción de Nitrógeno, Fósforo y Sulfuros en Agua Residual Doméstica, Utilizando Phragmites australis en Bioreactores. Inf. Tecnológica 2015, 26, 89-98. [CrossRef]

52. Lee, C.-G.; Fletcher, T.D.; Sun, G. Nitrogen removal in constructed wetland systems. Eng. Life Sci. 2009, 9, 11-22. [CrossRef]

53. Kujala, K.; Karlsson, T.; Nieminen, S.; Ronkanen, A.-K. Design parameters for nitrogen removal by constructed wetlands treating mine waters and municipal wastewater under Nordic conditions. Sci. Total. Environ. 2019, 662, 559-570. [CrossRef] [PubMed]

54. Zamora, S.; Marin-Muñiz, J.L.; Sandoval, L.; Vidal-Álvarez, M.; Carrión-Delgado, J.M. Effect of Ornamental Plants, Seasonality, and Filter Media Material in Fill-and-Drain Constructed Wetlands Treating Rural Community Wastewater. Sustainability 2019, 11, 2350. [CrossRef]

55. American Public Health Association (APHA). Standard Methods for the Examination of Water and Wastewater; American Public Health Association (APHA): Washington, DC, USA, 2005.

Sample Availability: Samples of the compounds are available from the authors.

Publisher's Note: MDPI stays neutral with regard to jurisdictional claims in published maps and institutional affiliations.

(C) 2020 by the authors. Licensee MDPI, Basel, Switzerland. This article is an open access article distributed under the terms and conditions of the Creative Commons Attribution (CC BY) license (http://creativecommons.org/licenses/by/4.0/). 